\title{
Velázquez, Wagner and the Red Skull. Intermediality and the Genesis of Meaning in a Particular Scene of Captain America: The First Avenger
}

\author{
Dániel Nagy \\ Eötvös Loránd University (Budapest, Hungary) \\ E-mail: nagydaniel.pecs87@gmail.com
}

\begin{abstract}
In the 2011 superhero movie, Captain America: The First Avenger (produced by Marvel Studios, directed by Joe Johnston) the main opponent of the title character is a Nazi officer, Johann Schmidt, who turns out to be a kind of superhuman entity, the Red Skull. Throughout the movie, viewers can follow the process of him gradually leaving behind his identity as a Nazi officer, and presenting himself as the leader of the occult-high-tech terrorist organization, the Hydra. At a certain point we can see him visited by one of the scientists working for him, Doctor Zola, whom he puts wise to his plans. During the conversation a portrait is being painted of the Red Skull, but we cannot see his face, only that the artist uses a huge amount of red paint. In the background, excerpts of Wagner's operas are being played, which is very unusual in a Marvel movie. The question is, should the viewer recognize the diegetic music and notice the possible reference to the painting Las Meninas by Velázquez? How the detection of these intermedial references and the awareness of the act of trespassing media borders would affect the semiotic processes of interpretation? And also, how would the more precise identification of the cited materials change the semiotic modality of intermediality here? The article tries to answer these questions by interpreting the scene and the role of the references in question within the entire film through the prism of intermedial semiotics.
\end{abstract}

Keywords: superhero movies, intermedial references, diegetic music, semiotics, genesis of meaning.

\section{Introduction. References and Meanings}

Certain cultural references in the 2011 Marvel movie, Captain America: the First Avenger (directed by Joe Johnston) - otherwise uncommon in the genre 
of superhero movies - present interesting problems in terms of intermediality. Namely, in what way exactly do the references to cultural objects of other media affect the meaning of the movie containing the reference? Are the viewers expected to recognize these references to understand the movie properly? Or do the references only convey additional information, which may modify the meaning of either a particular scene or of the entire movie, without being essential to the interpretation of the story as a whole? Or perhaps these are only "Easter eggs" created by movie makers at Marvel to flatter the vanity of their "over-educated" fans, who are able to notice them? Beyond the question of what the purpose of making such references in a superhero movie may be, it is also interesting from the point of view of intermediality studies why these are capable of serving any of the above-mentioned functions. I intend to discover some possible meanings generated by the intermedial references and I shall also attempt to reflect on the very process of generating meaning from a semiotic point of view.

\section{Wagner and Velázquez in the Company of the Red Skull}

Despite being a relatively short one (only ca. one-and-a-half-minute long), the scene in question has a vital role in the movie since it conveys a lot of information about the arch-villain character regarding his plans. Up to this point, he is known as a Nazi officer named Johann Schmidt, but we could also surmise that this is not his ultimate identity. It is already clear that his soldiers have found a magical relic called the Tesseract, which gives him and his organization, the Hydra (formerly a secret research division created by the Nazis) almost unlimited power. We also know that Dr Erskine - a scientist who is about to turn the feeble-bodied but mentally/morally steady Steve Rogers into a super soldier, a man of extraordinary physical power - had already used his formula on Schmidt back in Germany, but the serum amplified not only his physical power, but also his obnoxious personality traits, thereby creating a monster of him, a sort of evil Übermensch. After this, we can be absolutely sure that Schmidt is going to be the arch-rival of the positive hero (Captain America), following the conventions of superhero stories. However, at this point it is not yet clear how exactly Dr. Erskine's serum changed Schmidt, just that he became much more obsessed with power than he had been before the treatment.

Coming back to the scene in question: Schmidt is having a conversation with his leading scientist, Dr Arnim Zola, who designed the weapons which now, powered by the Tesseract, grant superiority to the Nazis over the Allies (or more exactly to Schmidt and the Hydra over everyone, including the Nazis, as it becomes clear 
shortly afterwards). In the scene we get to know that Schmidt has found out that Dr Erskine is now working for the Americans, and becomes concerned about Erskine's work, even though Dr Zola thinks that he would not succeed "again.” Accordingly, Schmidt orders that Erskine must be killed to eliminate the only possible danger which could frustrate his plans of world domination. But this is only half of the events taking place during the scene. Along with the conversation, a gramophone is playing music in the room, and there is also a third person present, a painter, making a portrait of the leader of the Hydra. One may find this simultaneous presence of two other art forms (or semiotic systems) on a diegetic level already quite unusual in a superhero movie, but the cultural references performed through them make the case even more complicated.

The end credits confirm it, too that the music played here is by Richard Wagner. More precisely, two excerpts can be heard from his monumental, four-evening cycle, The Ring of the Nibelung (Der Ring des Nibelungen). At the beginning, a scene of the cycle's second piece, The Valkyrie (Die Walküre) is played: the third scene of Act 1 with the so-called Wälse-cry (Wälse-Ruf) sung by Jon Vickers. A little while later, the music changes to a famous part of the Ring-cycle's concluding piece, The Twilight of the Gods (Götterdämmerung), namely Siegfried's Funeral March (Trauermarsch) from Act 3. According to the end credits, both excerpts are played by the Berlin Philharmonic Orchestra, conducted by Herbert von Karajan. Beyond the fact that this choice could be interpreted as acrimoniously ironic - knowing that his membership of the Nazi party was very often brought up against Karajan after the war, one might also wonder whether the particular scenes were cited here for a specific reason. Particularly since both are perfectly recognizable throughout the scene, especially the funeral march, which is one of the composer's most famous orchestral scenes; but any trained Wagnerian would also easily identify the Wälse-cry scene as well from the bars played in the movie. Though it might be a bold assumption that Marvel would have expected hardcore Wagnerians to watch their Captain America movie, it is still worth considering how it may modify the interpretation of the movie if someone realizes that the music of this particular scene already existed independently of the movie's soundtrack; even more so for we can see a gramophone playing music at the very beginning of the scene, which also lays an emphasis on the diegetic nature of it.

Mutatis mutandis, the same holds true for painting as well; we do not only see the canvas (though from behind) and the painter working on the portrait, at the very end of the scene, Schmidt explicitly asks Dr Zola's opinion about it, and the scientist considers it "a masterpiece." So the act of painting is not only diegetically shown in 
the movie, but is also thematized in the conversation of the characters, drawing our attention to it. Nevertheless, the case is a little bit more complicated here, since the viewers do not see the painting at all, only the verso of the canvas. What is more, we do not actually see the model of the portrait (Schmidt) either, for he turns off the lights at the very moment Dr Zola enters the room, and when he turns them back on - presumably to allow the scientist to gaze at the picture - we can only see Zola's flattering and the painter's haunted face. The question is: where can we witness such a sight, where can we see the back of a painting, a painter, and one or more possible viewers, but neither the painting (for the canvas turns its backside towards us) nor its subject (for it is outside the picture, just in our - the viewers' - position). In my opinion, this could be considered as a quite graspable reference to the famous picture Las Meninas by Diego Velázquez, painted in 1656 (on display in the Prado Museum in Madrid). In this much analysed painting, we can witness a situation very similar to the movie scene in question. The painter and all the other figures look at us, viewers, since we are in the position of the models, namely the Royal Pair (Phillip IV of Spain and his wife, Mariana of Austria), who we can see in the mirror on the wall behind the painter (even though art historians argued that this kind of double-portrait of the King and Queen never actually existed) (Arasse 2013, 140). As a matter of fact, this reference to fine arts is not as specific as the musical ones, that is to say, while the Wagner excerpts are doubtlessly identifiable (and they are even listed in the credits), the allusion to Velázquez may also be a mere play of fancy of an overinterpreting analytic mind. Nonetheless, it can be argued anyway that at least one actual viewer (the author of this paper) considered this mise-enscène in the movie a reference to Las Meninas. The question is, therefore, what might be the function of these references in the movie, and how this function is fulfilled from a semiotic point of view.

\section{From Intermediality to Interpretation}

As a matter of course, one must notice the references first of all to be able to attribute any kind of meaning to them. Moreover, the intermedial references can only become meaningful as intermedial references if they are perceived as trespasses of "constructed media borders" (Elleström 2010, 27). That is to say, the references in question may only obtain a semiotic function (i.e. becoming meaningful to someone in a certain context) as intermedial references once an interpreter starts interpreting them as, at least to a certain extent, alien elements in the given medial environment. In that case, their signification - or semiotic modality, to use the concept of Lars 
Elleström $(2010,21)$ - relies on the fact that they are being recognized as external references functioning as semiotic signs - or representamens (Peirce 1998, 163) -, representing cultural objects existing outside the genre of the superhero movie as well as its fictional world, thereby making the viewers aware of another act of trespassing, namely that they are using their knowledge and experience of the "real world" for understanding the "fictional" one. Consequently, the semiotic modality of intermediality not only "involves the creation of meaning in the spatiotemporally conceived medium by way of different sorts of thinking and sign interpretation" (Elleström 2010, 22), but in our case also presupposes a reflection upon the representative capacities of the above-mentioned acts of trespassing. Thus, the intermedial references analysed here not only represent something for someone in some context, but they are also representing their own representative character therefore they should be considered metaphors in the Peircian sense. ${ }^{1}$

This realization of the references' semiotic capacity, however, does not inevitably demand the precise identification of the specific cultural objects in question. In case of this particular scene, one may only become aware that the villain, Schmidt is listening to some piece of classical music, and a portrait is being painted of him throughout the scene. In this case, we could talk about systematic references (Systemreferenzen) here, since the references are made to another media instead of specific, individual works (Rajewsky 2005, 52-53). Accordingly, meaning attributed to the intermedial references would also proceed from values and concepts associated with classical music and fine arts in general.

For instance, one may interpret Schmidt's inclination toward these art forms as a sign of elitism, snobbery or hauteur. Many examples could be cited from movies or TV series in which sociopathic/psychopathic villainous characters are portrayed as having very developed taste in either classical music or fine arts - such as Hannibal Lecter in The Silence of the Lambs (Jonathan Demme, 1991) listening to classical music (the Goldberg-variations by Bach) in his prison cell, Magneto doing the same (with Mozart) in the X-Men movies, or Superman's arch rival, Lex Luthor, who also seems to be a fan of classical music. There are also a great many number of self-centred, negative characters who collect fine art to emphasize their wealth and high social status, such as Gordon Gekko from Wall Street (Oliver Stone, 1987) or Wilson Fisk from Netflix's Daredevil (2015-2018) series. Fitting into this tradition, the image of Schmidt listening to classical music and having a portrait painted of himself may also signify his aspiration to present himself as an exceptional person,

1 As Peirce states, "those [icons] which represent the representative character of a representamen by representing a parallelism in something else, are metaphors” $(1998,274$. 
one being better than others (e.g. Dr Erskine tells Steve that Schmidt forced him to use the serum on him for he wanted to become "more developed").

By contrast, his rival, Captain America appears for the first time as a kind of "people's champion," a living mascot of freedom and democracy, arousing patriotic spirit in soldiers and civilians, appearing in shows surrounded by vaudevillelike elements and popular songs. ${ }^{2}$ Therefore, from this point of view, the rivalry between good and evil could also be interpreted as a fight between the popular and the elitist, the democratic and the autocratic, the inclusive and the exclusive, the tolerant and the intolerant. The somewhat unexpected appearance of "high art" (classical music/opera and - supposedly - portrait painting) in the superhero movie may be endowed with semiotic modality through its contraposition with "popular art” (jazz-like popular songs, variety show elements, comic strip-like imagery, etc). This dichotomy makes the actualization of the above-mentioned connotations about "high art" (elitism, exclusivity, and so forth) possible by establishing a rather unambiguous semantic framework, in which intermedial references could be interpreted as symptomatic signs of the respective characters' personality traits.

What happens, however, if certain viewers are going much further in the identification of the cited material after all? How and why taking a step from systematic references toward individual ones (see above about Einzelreferenzen, Rajewsky 2005, 52-53) could affect the semiotic function fulfilled by these references? For instance, one could easily suppose - even without being an opera or classical music enthusiast - that the music played in the scene was composed by Richard Wagner. Firstly, because we hear a tenor singing in German and then a huge, romantic orchestra; and secondly because Schmidt is a Nazi officer and Wagner's compositions are often culturally associated with Nazism for historic reasons. Even if one does not realize the exact scenes from the Ring-cycle, which can be heard in the movie, one could attach different and actually more specific associations to Wagner's figure than to the notion of classical music in general. For one thing, the 19th-century German composer is widely known as Adolf Hitler's favourite musician, and also as an ardent anti-Semite himself. Thus, the presence of his music in the scene may arouse associations to the racist theories of the Nazis and their concept of social Darwinism, which eventually led to genocide, as it is

2 In fact, Captain America as a character was actually invented as a kind of patriotic propaganda figure - he appeared for the first time in March 1941, created by Joe Simon and Jack Kirby at Timely Comics (later Marvel Comics). On the cover of the very first issue, Captain America, wearing star-spangled costume from top to bottom, punches the Nazi leader, Adolf Hitler in the face. https://www.marvel.com/comics/issue/7849/captain_america_comics_1941_1. Last accessed 28. 01. 2019. 
commonly known. Therefore, listening to Wagner may characterize Schmidt as a person regarding himself a kind of an Übermensch, whose superiority implies that he has to either dominate or annihilate the inferiors. It is even more so as Wagner's music is also often associated with monumentality (thanks both to the length of his works and the huge numbers of required performers); ergo one might also interpret this citation as a sign foreshadowing the proportions of Schmidt's plans. Soon after we get to know indeed that he wants to use the power of the Tesseract to destroy all major European and American cities (including the German capital, Berlin) and take control over the whole world.

Seeing the painter and a viewer, but not the picture, one might also think of Velázquez, even without being aware of the immense interpretive tradition of Las Meninas. Or at least one may notice that only the acts of painting and watching are shown, but not the most essential part: the represented person himself. What we do see at first is the palette of the painter; he uses a huge amount of red paint for the portrait, and then we also see his face, which shows a mixture of abomination and horror. We already know that Schmidt has formerly been the subject of Dr Erskine's experiment, and at the very end of the scene we hear Dr Zola's flattering remark about the picture. But is it really about the picture? Since the viewer represented within the movie (Dr Zola) can only see the picture at the same time when he can also get the sight of Schmidt himself (in his real form), we cannot be absolutely sure whether his comment - "a masterpiece" - would actually refer to the portrait, or to Schmidt, as the Red Skull. Maybe art - represented here explicitly, on the level of the signifiers (Wolf 1999, 39-43) - serves not only as a mere signifier of the antagonist's attitude, but also as a complex metaphor for creativity, intellect and ambition, which could also result in destruction as well as in creation. The Red Skull and Captain America - being both Doctor Erskine's "creatures" in some sense - could come into existence thanks to the same serum. At the end of the day, we must realize that the creative invention turning Schmidt into an evil superhuman entity yearning for destruction and domination, and the one that made it possible for Rogers to become a virtuous guardian of justice, was one and the same. Similarly, the two inventor/scientist figures, Howard Stark for the Allies and Dr Arnim Zola for the Hydra both basically use their extraordinary talent to engineer weapons, though for different purposes.

In this context, "art" - appearing in the forms of Wagner's music and Schmidt's unseen portrait - can be regarded as a parallel, since throughout history artistic creativity could also be used to create beauty, while always remaining capable of spreading hatred and legitimizing oppression as well. The appearance of 
intermediality in the movie scene, therefore, results in an enhanced capacity for self-reflexivity (Ljungberg 2000, 94), and also in an extended semiotic potential. In addition to this, both of these capacities and potentials seem invigorating with the more precise identification of the references. On the one hand, the problematic nature of the cited artist figures and works (such as Wagner's widely known bigoted political views along with his much less debated creative genius) for instance may remind the viewer of the problematic relations within the movie's story as well (the good Captain America and the evil Red Skull being the results of eventually the same intellectual achievement, Dr Erskine's performance-enhancing serum). On the other hand, as the story of good and evil gets more complicated, ambiguity increases as well. It also implies that meaning, the "intended interpretant" of an expression from Peirce's point of view $(1998,220)$ will be less definite, but more complex at the same time. It seems that the more precise identification of the intermedial references triggers changes concerning their semiotic modality as well, since the associations or evaluations attached to more specific elements of culture such as the figures of certain artists or their works vary on a much wider scale than general associations about "art" or "high culture" in general. As the number of the references' perceived details gets higher, the possible ways of thinking about them multiply as well. Therefore, these references, as representamens, could refer to many different aspects of their respective objects, which also means that more space is left open for the interpretant and consequently, for the meaning. To put it in another way, their connotative aspect intensifies at the expense of the denotative aspect, thereby augmenting polysemy while decreasing univocality (Barthes 1990, $6-9)$. What happens then if we follow this path to the even further individualization of the references and try to interpret the entire movie according to the consequences of this interaction with specific works from other media? As mentioned above, the two Wagnerian scenes are the so called Wälse-cry from Act 1 of The Valkyrie, and Siegfried's funeral march from The Twilight of the Gods. In the first one, the hero, Siegmund laments that though he is about to fight against his enemy, Hunding the following day, he is still unarmed and therefore likely to die, in spite that his father, Wälse (who is also the chief god, Wotan) promised he would send him a sword when he (Siegmund) needed it most. The words are the following (in English translation by Frederick Jameson):

A sword, my father foretold me,

should serve me in sorest need.

Swordless I come to my foe-man's house;

as a hostage here helpless I lie: 
a wife saw I, wondrous and fair, and blissful tremors seized my heart.

The woman who holds me chained, who with sweet enchantment wounds, in thrall is held by the man who mocks his weaponless foe.

Wälse! Wälse! Where is thy sword?

The trusty sword, that in fight shall serve me, when from my bosom outbreaks the fury my heart now bears? ${ }^{3}$

As a matter of fact, the conversation in the scene is also about possessing mighty weapons and about being weaponless. Schmidt literally tells Dr Zola that "[Dr Erskine's] serum is the Allies' only defense against this power we now possess. If we take it away from them, then our victory is assured." That is to say, Schmidt/the Red Skull and his side are in the position of Hunding, at least in terms of being armed, while the Allies, like Siegmund, are preparing for a decisive clash having only one faint ray of hope to acquire what is needed to fight with a chance of victory (though at this point they - unlike Siegmund in Wagner's music drama - are unaware of this). Thus, the superpowers granted by the serum to Steve Rogers (thereby creating his superheroic alter ego, Captain America) would be like Nothung, a sword pulled out from the trunk of a tree by the one who is worthy of wielding it.

Unfortunately, however, the outcome of the fight for Siegmund is not positive at all, for he gets slain in the duel - thanks to a divine intervention by Wotan, who also kills Hunding shortly afterwards. Similarly, in some sense, both the Red Skull and the Captain get killed during their decisive clash at the end of the movie. And here, the second Wagner citation, the funeral march makes things much more complicated and interesting. In The Twilight of the Gods this music accompanies the procession carrying the body of Siegfried back to the Gibichung Hall from the hunt on which he got slain (from behind) by Hagen, who eventually dies by drowning in the flooding river Rhine when he tries to acquire the ring from Siegfried's dead hand. In the figures of these two heroes Wagner apparently makes use of the ancient mythological

3 "Ein Schwert verhieß mir der Vater, / ich fänd" es in höchster Noth. / Waffenlos fiel ich in Feindes Haus; / seiner Rache Pfand, raste ich hier: / ein Weib sah'ich, wonnig und hehr: / entzückend Bangen zehrt mein Herz. / Zu der mich nun Sehnsucht zieht, / die mit süßem Zauber mich sehrt, / im Zwange hält sie der Mann, / der mich wehrlosen höhnt. / Wälse! Wälse! Wo ist dein Schwert? / Das starke Schwert, / das im Sturm ich schwänge, / bricht mir hervor aus der Brust, / was wüthend das Herz noch hegt?” Richard Wagner, Die Walküre, 94-98. 
topos of the twins (Lévi-Strauss 1979, 26-35), though they are not literally born from the same mother, but approximately at the same time, being the descendants of the cycle's two arch rivals, Wotan and Alberich, thereby destined to struggle against each other in some way. Accordingly, one kills the other (though not in proper combat) and then drowns when trying to get the magical artefact capable of granting power sufficient for world domination. In this way, the Tesseract can be paralleled with the ring, and Captain America and the Red Skull with Siegfried and Hagen. But which one of them would play which role? The obvious choice would be that Siegfried was the Captain, and the villainous Red Skull was Hagen, the intriguer. But this is not the case apparently. The one who manages to take advantage of his rival's hybris and thereby slay him and get drowned afterwards - in one word, "the Hagen" of this story - is definitely the one who is supposed to be the "good guy," Captain America. At the same time, the "free hero," having been born against his creator's will, then acquiring the magical artefact which could provide him almost unlimited power and finally dying exactly because he is not willing to give up this power - i.e. "the Siegfried" character - is Schmidt, as the Red Skull. Naturally, Captain America in the movie does not backstab anyone, for he is portrayed as a righteous warrior, a champion of courage, honesty and decency. He does not let himself be lost in the Atlantic Ocean for he wants the power of the Tesseract to himself either, rather for he tries to save the lives of innocent people. Nevertheless, the Wagner references may still make us reflect upon our expectations about the main antagonism of the story. The motivic parallelisms with the story of the Ringcycle are undeniable on the one hand, but on the other hand also confusing in regard to the outcome of the conventional superhero story. Although on the surface the movie seems to present Rogers/Captain America as essentially good and Schmidt/ the Red Skull as essentially evil, their parallelism with Wagner's heroes appears to undermine our belief about the necessity of their moral choices. Although Captain America could be paralleled more with Hagen than with Siegfried, he is still neither an intriguer nor a villain in the movie. At the same time, Schmidt/the Red Skull, despite his likeness to Siegfried in many aspects, is not only portrayed as naive and overbold, but also as a selfish, unscrupulous power-monger. This may lead us to the conclusion that the dichotomy between heroes and villains is actually much more problematic than it seems at first sight, even in superhero stories.

In the case of the presumable reference to Velázquez, a similarly thoughtful examination may also result in equally perplexing interpretations. Going beyond the formal parallelisms between Las Meninas and the portrait of the Red Skull (i.e. we only see the back of the canvas and the figure of the painter among others, but 
never the actual subject of the portrait), one may wonder whether the extremely rich interpretation history of the invoked painting could also become part of the interpretation of the movie scene referring to it. The most famous and influential interpretation of Velázquez's work is unquestionably the one by the French philosopher, Michel Foucault. The questions brought up in his analysis at the beginning of the book The Order of Things (Les mots et les choses) have remained fascinating ever since its first publication in 1966 (Foucault, 2002, 3-18). In this essay, Foucault points out that while watching the painting we see the painter watching us, onlookers, for we are in the position of his model, thereby "the observer and the observed take part in a ceaseless exchange" (Foucault 2002, 4-5). That also means we - the viewers, in position of the models - "do not know who we are, or what we are doing” (Foucault 2002, 5), yet we still become part of the picture. Therefore "the entire picture is looking out at a scene for which it is itself a scene" (Foucault 2002, 15). This means that the represented subject (originally the royal pair) determines representation from the outside; therefore the picture itself could be interpreted as the pure form of representation, the representation of representation (Foucault 2002, 17-18).

If one then tries to interpret the last cut of the scene in the light of the above, first of all one may realize that in this very context, being in the position of the painter's model as an observer/viewer equals to being in the position of the villainous Red Skull. When the light is turned on, enabling Dr Zola to catch a glimpse on his super evil boss - he is actually staring at us. This all too disturbing recognition could make us remember that evil is maybe not something essentially alien to us, but at some level it may be hiding within every single person, including ourselves. The intermedial reference in which the medium of painting trespasses into the superhero movie could lead to such perplexing thoughts otherwise quite unexpected in the genre.

But one could follow this reference even further. For instance, considering Foucault's explanation of Velázquez's painting, and thinking through the scene accordingly, could bring forth even more abstract ideas. By now, the French philosopher's highly influential book - even though many argued especially against its thoroughly anachronistic analysis of Las Meninas - has become part of the interpretation history of the 17th-century Spanish master's painting. Therefore, the picture itself (evoked by an intermedial reference in the movie scene under discussion) could also be a reference to the philosophical theory which used it as a starting point of its argumentation. If we, then, accept that it could be interpreted as the representation of the classical paradigm of representation, as Foucault suggested (2002, 17-18), it would give yet another layer to our understanding of the movie scene. 
The most conspicuous parallelism between the painter on Velázquez's picture (presumably working on a portrait of the royal pair) and the unnamed artist in the movie (painting the Red Skull in his headquarters) is the person(s) they are painting. More precisely, the quality shared by their unseen models - they both paint not the beautiful, but the powerful. The distressed facial expression of the artist in the movie tells it all - in all probability, he paints out of fear. This raises a fundamental question about the very nature of representation: is it actually about either aesthetics or truth in a philosophical sense, or rather it is first and foremost about power? Is it not the case that what Foucault labels as "classical representation" never actually reflects reality in its pure form, rather it presents only a construction, something which is designed to please the powerful? ${ }^{4}$ Could it not be the case that the trespassing of media borders here underlines yet another inevitable trespassing: the influence of power (in our case the sheer capacity for physical violence) over any kind of representation? Or just as media borders are created by mere conventions (Elleström 2000, 28), maybe the borders between artistic representation and political/military power are also nothing but virtual lines drawn to reassure our illusions?

Interestingly, this problem is raised once again in the movie, for the figure of Captain America is not at all a superhero at first. Although Dr Erskine's treatment turns Steve Rogers into a possible super soldier, his alter ego, Captain America is only used as a propaganda figure, a living patriotic poster, encouraging Americans to subscribe to war bonds. Even when he is finally sent to Europe, he does not engage in real combat against actual German soldiers, just provides entertainment for the troops appearing in variety shows. He is even mocked and booed by soldiers for being a fake, not a real warrior, who puts his own life at stake for victory. It seems like the movie would even offer the possibility of a deconstructive view about the very concept of superheroes as mere propaganda figures, despite being a superhero story itself. This could also arouse the viewers' suspicion about the conventions of representation specifying the design of various things from the portraits of 17th-century absolute monarchs to media coverages of contemporary armed conflicts and beyond, whether they are also shaped mainly to serve the interests of those in charge. Could the representation of representation warn us not to trust representation without reservation? Should one always seek for the traces of power behind the conventions when one tries to interpret anything represented?

4 At this point, the interpretation of the work making the reference might relate back to the interpretation of the work to which the reference is made. Perceiving the structures of power in the relation of the Red Skull and his pictorial representation, one may also start wondering about the structures of power inherent in Velázquez's painting as well, a point which Foucault himself may have found interesting. 
Naturally, these interpretations are only some of the many possible ones, which show that - in our case at least - the individualization of the intermedial references leads to a wider range of possible meanings, and that these meanings will also be more debatable at the same time. The question is: what are the semiotic grounds and consequences of this phenomenon?

\section{Conclusion. The Expansion of Meaning: Entropy}

As presented above, from a semiotic point of view, the intermedial associations may open new fields for interpretation by initiating new references to the interpretive horizon of the recipients and thus creating new connotations or new interpretants. At the same time, this proliferation of connotations and interpretants equals the proliferation of possible meanings.

Although it seems that such proliferation also goes hand in hand with the increase of the sense of disorder, Umberto Eco warns us that "certain elements of disorder may in fact increase the level of information conveyed by a message" - which holds especially true for works of art of any kind (Eco 1989, 53). The deliberate disorganization of a poetic message, in other words, its improbability in relation to a precise system of probability, makes it much more informative for its recipients (Eco 1989, 54). Unusuality and unpredictability may therefore result in a surplus of information in certain circumstances (Eco 1989, 55). Thus, according to Eco, even if it is more difficult to communicate more disordered messages, they certainly carry larger amounts of information than clearer messages, which are easier to communicate $(1989,57)$. Or, to put it in another way, the volume of information carried by a certain message may also be defined as directly proportional to the entropy of expression (Eco 1989, 57).

The concept of information used here, however, must not be confused with meaning; it is more like a measure of one's freedom of choice when selecting a message than one particular message (Eco 1989, 57). Another semiotician, Yuri Lotman formulates this by referring to the Soviet mathematician, Andrei Kolmogorov, stating that the "information volume" (or language entropy: $\mathrm{H}$ ) could be defined as the sum of the semantic capacity of the language (its ability to transfer meaningful information in a certain text/artefact) and the flexibility of the language (the number of possible ways in which the same content could be transferred) (Lotman 1977, 2631, see also Semenenko 2012, 32-33). The flexibility and variability of an artistic code therefore result in higher information volume, for they imply more freedom of choice in the process of encoding certain "artistic messages." 
As for meaning, this implies that if the volume of information is determined by the flexibility of the language, or can be measured with the degree of the freedom of choice in the process of encoding, then the richness of aesthetic meaning, consequently, is determined by the flexibility of the message, and it could be measured with the degree of freedom of choice in the process of decoding. In simple terms, meaning is the number of the possible ways in which the same message could be interpreted. Which means that the more semiotic potentials (Cook 2001, 179 and 1994, 221-222) are comprised within a certain message (i.e. the higher is the number of ways in which it may become actually meaningful to any actual recipient), the richer its meaning will be. But how exactly does this happen in our case? How can the individualization of references be held responsible for the increase of entropy and the proliferation of semiotic potentials?

In my opinion, the individualized intermedial references present alternatives for similar representations from different epochs and media, thereby taking any possible interpreter to see that similar messages could have been endowed with different meanings in different medial, historic, social or cultural contexts. In one word, all of the cited individual works evoke their respective contexts, and the more these contexts get involved in our interpretation, the broader our interpretive horizon becomes. To put it in more semiotical terms, the field of the Peircian interpretant would expand, or the number of Barthesian connotations would increase (see above). As a matter of course, this extended horizon also implies that the different invoked contexts could produce different or even contradictory interpretations simultaneously. As on the one hand the number and complexity of possible meanings grow, the determination of meaning fades on the other (Szívós 2017, 265-266). The richer the meaning becomes, the more ambiguity and opacity it gets; while the clearer and less problematic it is, the more banal and platitudinous it becomes (Eco 1989, 57 cited above). This has been shown in my example, where the conventional superhero story about the clash of good and evil could be efficiently challenged in a number of ways by drawing an extended knowledge about Wagner's or Velázquez's works into the interpretation. Though the interpretations taking form as a result are all debatable (for they are inevitably ambiguous), they undeniably embrace more complexity as well compared to any interpretation ignoring these references.

Apart from the movie in question, or even intermediality, it may be identified as a general rule that in the more different contexts we examine something, the less simple and non-contradictory it will appear. The complexity and ambiguity of meanings in works of art of different media are only reflecting the complexity and 
ambiguity of human experience. This may be the most important lesson intermedial references could teach us.

\section{References}

Arasse, Daniel. 2013. The Eye of the Master. In Take a Closer Look, 131-159. Princeton - Oxford: Princeton University Press.

Barthes, Roland. 1990. S/Z. Oxford: Blackwell Publishing.

Captain America. In Marvel Comics Database. https://www.marvel.com/comics/ issue/7849/captain_america_comics_1941_1. Last accessed 28. 01. 2019.

Cook, Nicholas. 2001. Theorizing Musical Meaning. Music Theory Spectrum vol. 23, no. 2 (Fall): 170-195.

Eco, Umberto. 1989. The Open Work. Cambridge, Massachusetts: Harvard University Press.

Elleström, Lars. 2010. The Modalities of Media: A Model for Understanding Intermedial Relations. In Media Borders, Multimodality and Intermediality, ed. Lars Elleström, 11-48. London, New York: Palgrave Macmillan.

Foucault, Michel. 2002. The Order of Things: An Archeology of the Human Sciences. London - New York: Routledge Classics.

Lévi-Strauss, Claude. 1979. Myth and Meaning. New York: Schocken Books.

Ljungberg, Christina. 2000. Intermedial Strategies in Multimedia Art. In Media Borders, Multimodality and Intermediality, ed. Lars Elleström, 81-95. London, New York: Palgrave Macmillan.

Lotman, Jurij. 1977. The Structure of Artistic Text. Ann Arbor: University of Michigan Press.

Melrose, Susan. 1994. Semiotics of the Dramatic Text. London: Macmillan.

Peirce, Charles Sanders. 1998. The Essential Peirce - Selected Philosophical Writings. Vol. 2. Bloomington, Indianapolis: Indiana University Press.

Rajewsky, Irina O. 2005. Intermediality, Intertextuality, and Remediation: A Literary Perspective on Intermediality. Intermedialités no. 6 (Automne): 43-64.

Semenenko, Aleksei. 2012. The Texture of Culture - An Introduction to Yuri Lotman's Semiotic Theory. New York - Houndmills, Basingstoke, Hampshire: Palgrave Macmillan.

Szívós, Mihály. 2017. A jeltól a kódig [From the Sign to the Code]. Budapest: Loisir. Wagner, Richard. [n.d.] Die Walküre [The Valkyrie]. Mainz: B. Schott und Söhne. Wolf, Werner. 1999. The Musicalization of Fiction. A Study in the Theory and History of Intermediality. Amsterdam - Atlanta, GA: Rodopi. 